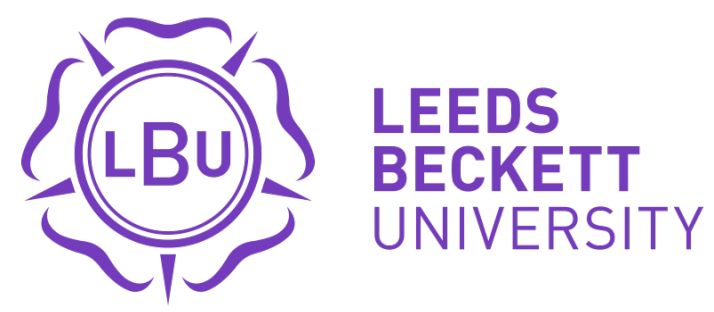

Citation:

Ntoumanis, $\mathrm{N}$ and $\mathrm{Ng}$, JY and Barkoukis, V and Backhouse, SH (2015) A philosophical debate on the morality of doping is interesting but beyond the scope of our meta-analysis. Sports medicine (Auckland, N.Z.), 45 (3). 445 - 446. ISSN 0112-1642 DOI: https://doi.org/10.1007/s40279-015-0315-x

Link to Leeds Beckett Repository record:

https://eprints.leedsbeckett.ac.uk/id/eprint/1259/

Document Version:

Article (Accepted Version)

The aim of the Leeds Beckett Repository is to provide open access to our research, as required by funder policies and permitted by publishers and copyright law.

The Leeds Beckett repository holds a wide range of publications, each of which has been checked for copyright and the relevant embargo period has been applied by the Research Services team.

We operate on a standard take-down policy. If you are the author or publisher of an output and you would like it removed from the repository, please contact us and we will investigate on a case-by-case basis.

Each thesis in the repository has been cleared where necessary by the author for third party copyright. If you would like a thesis to be removed from the repository or believe there is an issue with copyright, please contact us on openaccess@leedsbeckett.ac.uk and we will investigate on a case-by-case basis. 


\title{
A philosophical debate on the morality of doping is interesting but beyond the scope of our meta-analysis.
}

\section{Authors}

\author{
Nikos Ntoumanis \\ Curtin University, Australia \\ Johan Y. Y. Ng \\ The Chinese University of Hong Kong \\ Vassilis Barkoukis \\ Aristotle University of Thessaloniki, Greece \\ Susan Backhouse \\ Leeds Beckett University, UK
}

Address for correspondence:

Nikos Ntoumanis, $\mathrm{PhD}$

Health Psychology \& Behavioural Medicine Research Group

School of Psychology \& Speech Pathology

Curtin University,

GPO Box U1987

Perth, Western Australia, 6845

Email: Nikos.Ntoumanis@curtin.edu.au

Dear Editor,

We would like to thank Dr Arandjelovic [1] for taking the time to read our meta-analysis, which statistically synthesized the personal and psychosocial predictors of doping use in sport and other physical activity settings. Unfortunately, his remarks reveal a misunderstanding regarding the scope of our paper. In essence, Dr Arandjelovic charged us with 'seasoning' our science with moralistic bias. He then presents a number of philosophical questions that, although important and relevant to 
the doping landscape, have nothing to do with our meta-analysis or the studies contained within it. This distance between our work and the philosophical challenges to anti-doping policy and practice is further underscored by the invitation to engage in an intellectual debate on these issues in a sports ethics or medical ethics journal.

It is worth reiterating that our meta-analysis was not conceived to examine current anti-doping policy and practice, nor to present views in favor or against the moral aspect of doping/performance enhancing drug use. Our meta-analysis served to objectively analyze empirical studies examining doping intentions and doping use in order to determine the strongest psychosocial correlates (both positive and negative), as well as potential moderator variables. The included empirical studies tested, among other predictor variables, morality-related variables such as moral norms and moral disengagement, variables that we obviously included in our review. In our discussion, and on the basis our results, we (very) briefly state that the findings highlight the significance of morality in preventing doping use. Whilst we advocate intellectual debate on issues relating to current anti-doping policy and practice, and we are cognizant of the arguments in favor of the legalization of doping in sport [2-5], these are moot points beyond the scope of our meta-analysis. Further, these articles did not test personal or psychological predictors of doping use and, thus, were not included in our meta-analysis.

We are also responding to Dr Arandjelovic because we feel that the readers might benefit from reading our views on the issues that he raised in his letter. The 'doping is illegal' heuristic is commonplace in the literature describing doping substances and behaviors [6-10]. Inclusion of the term 'illegal' in the context of our study reflects a dialogical process of interpretation whereby 'illegal' relates to the intentional breaking of anti-doping rules, through the use of Prohibited substances and methods. These rules are constituted and enforced within the sporting context [11]. To illustrate, an athlete from any country who participates in sport under the authority of any signatory of the World Anti-Doping Code (WADC), Government, or other sports organisation accepting the Code, found to have administered testosterone enanthate without a therapeutic use exemption, would face sanction for committing an anti-doping rule violation. Having said this, we are mindful that we might have conveyed the view that doping is simply about the use of Prohibited substances and methods. To clarify, the World Anti-Doping Agency's (WADA) definition of doping 
is far more encompassing. Taken directly from the WADC, doping is defined as "the occurrence of one or more of the anti-doping rule violations set forth in Article 2.1 through Article 2.10 of the Code" [12, p.18]. In Article 2.1 a rule violation is the "Presence of a Prohibited Substance or its Metabolites or Markers in an Athlete's Sample". Similarly in Articles 2.2, through to 2.10, rule violations include the use or attempted use, possession, trafficking and administration or attempted administration of a "Prohibited Substance or Prohibited Method" [12].

In the context of health and fitness, we agree that the issue of morality is questionable and alternative perspectives need to be viewed. In fact, the morality variables included in our review were predominantly from competitive sport samples, not recreational athletes. Nevertheless, it is interesting to note that the International Federation of Bodybuilding and Fitness (IFBB) has accepted the Code and has been an official Signatory to the Code since 2003. In its preface to the Anti-Doping Rules [13] it states that the adoption and implementation of the Code is in furtherance of the "IFBB's continuing efforts to eradicate doping in the sports it governs" (p.1). The IFBB also encourages national associations to incorporate active anti-doping programs.

In some countries (e.g., Denmark), fitness enthusiasts risk social or financial sanctions from the National Anti-Doping Organisation (NADO) if they contravene anti-doping rules [14]. Whilst many NADO's do not currently intervene in this way, such initiatives appear to be motivated by a desire to promote gyms and fitness centers as 'clean' exercise environments [15]. It is worth noting that in the 2011 Communication on Sport [16] it was stated that doping remains "an important threat to sport. Use of doping substances by amateur athletes poses serious public health hazards and calls for preventive action, including in fitness centers" (p.6). Despite this assertion, there are no reliable estimates around the current prevalence of self-directed performance and image enhancing drug use in sport and fitness contexts and this absence of evidence needs to be addressed.

We do not disagree with Dr Arandjelovic's concerns about applying a detection-deterrence model in a fitness setting; it will likely be impractical and counterproductive. Still, if the threat to public health is real, there is a need to consider a preventive framework that incorporates prevention, treatment and after-care [14]. As 
such, we stand by our focus on prevention in the paper, and Dr Arandjevolic's call for a harm-minimization approach would fit within this prevention framework. 


\section{References}

1. Arandjelović O. Doping use meta-analysis: Science seasoned with moralistic prejudice. Sports Med.

2. Kayser B, Mauron A, Miah A. Viewpoint: Legalisation of performance-enhancing drugs. Lancet. 2005;366(Special Issue):S21.

3. Kayser B, Mauron A, Miah A. Current anti-doping policy: a critical appraisal. BMC Med Ethics. 2007;8(1):2.

4. Savulescu J, Foddy B, Clayton M. Why we should allow performance enhancing drugs in sport. Br J Sports Med. 2004;38(6):666-70.

5. Savulescu J, ter Meulen R, Kahane G. Enhancing human capacities. New York: John Wiley \& Sons; 2011.

6. Brand R, Heck P, Ziegler M. Illegal performance enhancing drugs and doping in sport: a picture-based brief implicit association test for measuring athletes' attitudes.

Subst Abuse Treat Prev Policy. 2014;9(1):7.

7. Deventer K, Roels K, Delbeke FT, et al. Prevalence of legal and illegal stimulating agents in sports. Anal Bioanal Chem. 2011;401(2):421-32.

8. Kadi F. Cellular and molecular mechanisms responsible for the action of testosterone on human skeletal muscle. A basis for illegal performance enhancement. Br J Pharmacol. 2008;154(3):522-8.

9. Pitsch W, Emrich E, Klein M. Doping in elite sports in Germany: results of a www survey. Eur J Sport Soc. 2007;4(2):89-102.

10. Thieme D, Hemmersbach P. Doping in sports. Heidelberg, Germany: Spinger; 2010.

11. Kirkwood K. Defensive doping: Is there a moral justification for "if you can't beat 'em - join 'em?”. J Sport Soc Issues. 2012;36(2):223-8.

12. WADA. World anti-doping code. Montreal, Canada: World Anti-Doping Agency; 2015.

13. International Federation of Bodybuilding and Fitness. IFBB Antidoping Rules 2015. 2014.

14. European Union. Study on doping prevention: A map of legal, regulatory and prevention practice provisions in EU 28. Luxembourg: Publications Office of the European Union; 2014. doi:10.2766/87088.

15. Christiansen AV. Bodily violations: Testing citizens training recreationally in gyms. In: McNamee M, Møller V, editors. Doping And Anti-Doping Policy In Sport: Ethical, Legal And Social Perspectives London: Routledge; 2011. pp. 126-41.

16. European Union. Communication on sport: Developing the European dimension in sport. Belgium: Publications Office of the European Union; 2011. doi:10.2766/16859. 